An International Multidisciplinary Journal, Ethiopia Vol. 7 (3), Serial No. 30, July, 2013:196-216

ISSN 1994-9057 (Print)

ISSN 2070--0083 (Online)

DOI: http://dx.doi.org/10.4314/afrrev.v7i3.15

\title{
Recharging the Lake Chad: the Hydropolitics of National Security and Regional Integration in Africa
}

Ifabiyi, I. P. - Department of Geography and Environmental Management, University of Ilorin

E-mail: tokunifabiyi@yahoo.com

Phone no: 08033231626

\begin{abstract}
s
Lake Chad, the 6th largest lake in the world, has hydrographical basin area of 2,381,631 km $\mathrm{km}^{2}$, an active basin of $966,955 \mathrm{~km}^{2}$; it is a source of fresh water, fisheries, pastoral and agricultural land in Algeria, Cameroun, CAR, Chad, Libya, Niger, Nigeria, and Sudan with a population of 30 million spread across. Lake Chad is under the threat of climatic change. It has reduced from 25,000km 1963 to $2,000 \mathrm{~km}^{2}$ in 2010. According to the President of Nigeria, this lake may disappear within 20 years. Desiccation of Lake Chad has various consequences on hydrological regimes, water pollution, biodiversity, ecosystem, sedimentation, security, livelihood, regional stability, etc. These consequences are mostly felt in Nigeria. In an effort to overcome these problems, the concept of TRANSAQUA was muted to transfer water from the Congo basin. This involves the construction of $2,500 \mathrm{~km}$ navigable channel from the Ubangi River in the Congo basin to recharge the lake. Indeed, a recharge of the lake will not only make the
\end{abstract}


basin more active, it will facilitate navigation, generate electricity, regulate river regime, clear land lockedness, re-establish fishery and irrigation, promote poverty alleviation, mitigate drought, and check desertification. All these will facilitate economic development and enhance regional integration. This paper makes a case for water recharge in Lake Chad basin, studies IBWT project in the Lake Chad region and analyses its implication on Nigeria and Africa South of Sahara.

\section{Introduction}

Inter-basin water transfer (IBWT) is a water conveyance scheme which is designed to move water from one river basin to another where water is less available or where water could be utilized better for human development. Purposes of this include provision of water for electricity, urban water supply, navigation, irrigation, political purposes, etc. Inter-basin water transfer is a complex exercise with various components.

Climate change phenomenon is an important phenomenon which can promote IBWT. For example, in Nigeria there are growing evidences of climate change in the sub region. This phenomenon has several attendant consequences. Ahmad and Ahmad (2000), IPCC (2001), NEST (2003), and Hangaveled et al (2005) all reported increasing temperature, increasing evapotranspiration, decreasing rainfall amount in continental interiors, increasing rainfall in the coast, increasing intensity of weather related disaster such as thunderstorm, lightening, landslides, floods, droughts, bush fire, unpredictable rainfall pattern, sea level rise, increase desertification, and land degradation, drying up of rivers and lakes and constant loss of forest cover and biodiversity. Also, Increasing frequency and intensity of unusual or extreme weather related events such as erratic rainfall pattern floods and sea level rise have also been reported (Odjugo, 2005; 2009, Molega, 2006; Nnodu et al; Umoh, 2007). Political conflicts induced by climate change on water resources have been recorded in every part of west Africa such as the downstream half of Niger river between Nigeria and Niger, in the middle valley of Senegal- between Senegal and Mauritania, and in the Volta river area between Ghana and Burkina Faso, the southern part of lake Chad between Cameroun and Nigeria, etc (Niasse, 2005). The above evidences point to the fact that every part of Nigeria, particularly the sudano-sahelian is already living with climate change, rather what is of importance are studies of its impacts and peoples adaptive strategies to the change on resources and livelihood patterns. The direct consequences of climate change 
in the Nigeria Sahelian zone are: heavy precipitation, damages to properties such as blown roofs, collapsed building, increasing case of fire incidences, soil erosion by water and wind, drying sources of water, drought, siltation and sedimentation of water bodies, menace of water weeds. In Nigeria this scenario is further complicated by the prevailing socio economic situation, as clearly indicated by the certain socio economic indices of the region of Nigeria that are located within the Chad basin. According to a recent data released by NBS (2012) Yobe state has the highest rate of youth unemployment, a rate greater than $21 \%$ recorded for the country. The level of poverty in Nigeria has also been on the increase, $69 \%$ of Nigeria population is found to be poor, despite GDP growth rate of $7.75 \%$. Even, more pathetic is the fact that poverty level has been on the increase. Poverty margin increased from $54.4 \%$ in 2004 to $71.5 \%$ in 2011, more importantly, the Lake Chad region of northeast Nigeria is found to have one of the highest levels of $76.3 \%$. Borno state only $2 \%$ of children under 25 months has been vaccinated, $83 \%$ of young people are illiterates, and $48.5 \%$ of children do not go to school. The increasing poverty, unemployment, illiteracy coupled with religious radicalism, has giving rise to terrorism

Recent estimate puts the water supply and sanitation coverage at 58 percent and 32 percent respectively for urban and rural communities (Water Aid Nigeria, 2011; WHO and UNICEF, 2010). Access to water and basic sanitation in Nigeria is relatively low with a proportion of 47 percent and 30 percent respectively (Attah, 2009). Recent analysis revealed that access to improved sources of water in Nigeria decreased from 60 percent in 1990 to 47 percent in 2006 (WSMP, 2009). Less than $28 \%$ of the households in Nigeria use improved sources of drinking water and basic sanitation (NBS, 2008). It is estimated that over two thirds of the diseases affecting Nigerians particularly children who are under-five is due to poor water supply and sanitation (UNICEF, 2010). Therefore in order to protect livelihood and conserve the ecosystem in such communities, IBWT remains one of the few choices. It involves adequate feasibility studies, legal frameworks, riparian rights especially along transnational basins; it has effects on aquatics, water conservation,

Inter-basin water transfer projects can be found in all parts of the world, many examples are found in Australia, Canada, China, India and the United States. The oldest example dated back to the late 19th century. The primary purpose of IBWT is either to alleviate water scarcity or to generate hydropower. Some of the examples are listed in table 1. 


\section{The Lake Chad basin}

Lake Chad is located between latitude $12^{\circ} 00 \mathrm{~N}$ and $14^{\circ} 30^{\prime} \mathrm{N}$ and Longitudes $13^{\circ} \mathrm{E}$ and $15^{\circ} 30^{\prime} \mathrm{E}$. The Nigerian portion of the basin is about $200,000 \mathrm{~km}^{2}$; it is the 4th largest lake in Africa, sustaining 37 million people, it forms the boundary of 4 littoral states. It is faced by climate change problem and brought on a sharper focus by anthropogenic activities. It has shrunk by about $90 \%$. The Inhabitants have no domestic water sources, clean or unhygienic water sources. They suffer from unavoidable malnutrition, diseases due to poor sanitation. The repeated drought of 1970s and 1980s is responsible for continuous emaciation of the water resources. It is affected by wind erosion, wind, siltation, drought, and desertification. These have affected fisheries, agriculture, livestock, ecosystem, etc. Lake Chad is a source of fresh water, fisheries and pastures.

The nations in the basin have a combined total population of 237 million people projected to reach 390 by 2025 . Urbanization in the basin is about $50 \%$, it is projected to $70 \%$ in 2030 . Lake Chad is a home to 120 fishes and 372 birds.

According to Dami, et al. (2011), the Lake Chad basin comprises five bioclimatic zones, namely: Saharan, sahelo-saharan, sahelo-sudanian, sudano-sahelian and sudano-guinea ecological zones. South-west humid Atlantic (monsoon) and the north-east Egyptian hot and dry (harmattan) currents influence the climate and consequently the ecological zonation of the basin. The sudano-guinean climate in the south for example, has an average annual rainfall of over 950 millimeters, a rainy season of six to seven months (May-November) with an average annual temperature at Sarh (formerly Fort Archambault in Chad) of $28^{\circ} \mathrm{C}$ (absolute minimum $10^{\circ} \mathrm{C}$, absolute maximum $45^{\circ}$ ) and annual Piche-recorded evaporation of $2027 \mathrm{~mm}$ in 1961. During the winter months, the cool, dry, dust-laden "harmattan" blows from the Saharan in the north, bringing low humidity, cool nights and warm days. In summer months, moisture-laden winds blow from the Gulf of Guinea in the south bringing high humidity, rains, and more uniform diurnal temperature. The monsoon advances from the south, so that rains start earlier, are heavier and last longer in the southwards, although in general there is high spatial and temporal variability over the entire area. The terrain of the study area is generally flat with a few shallow depressions and a few widely scattered elevated spots. The resulting surface drainage density is low (LCBC, 2007). 

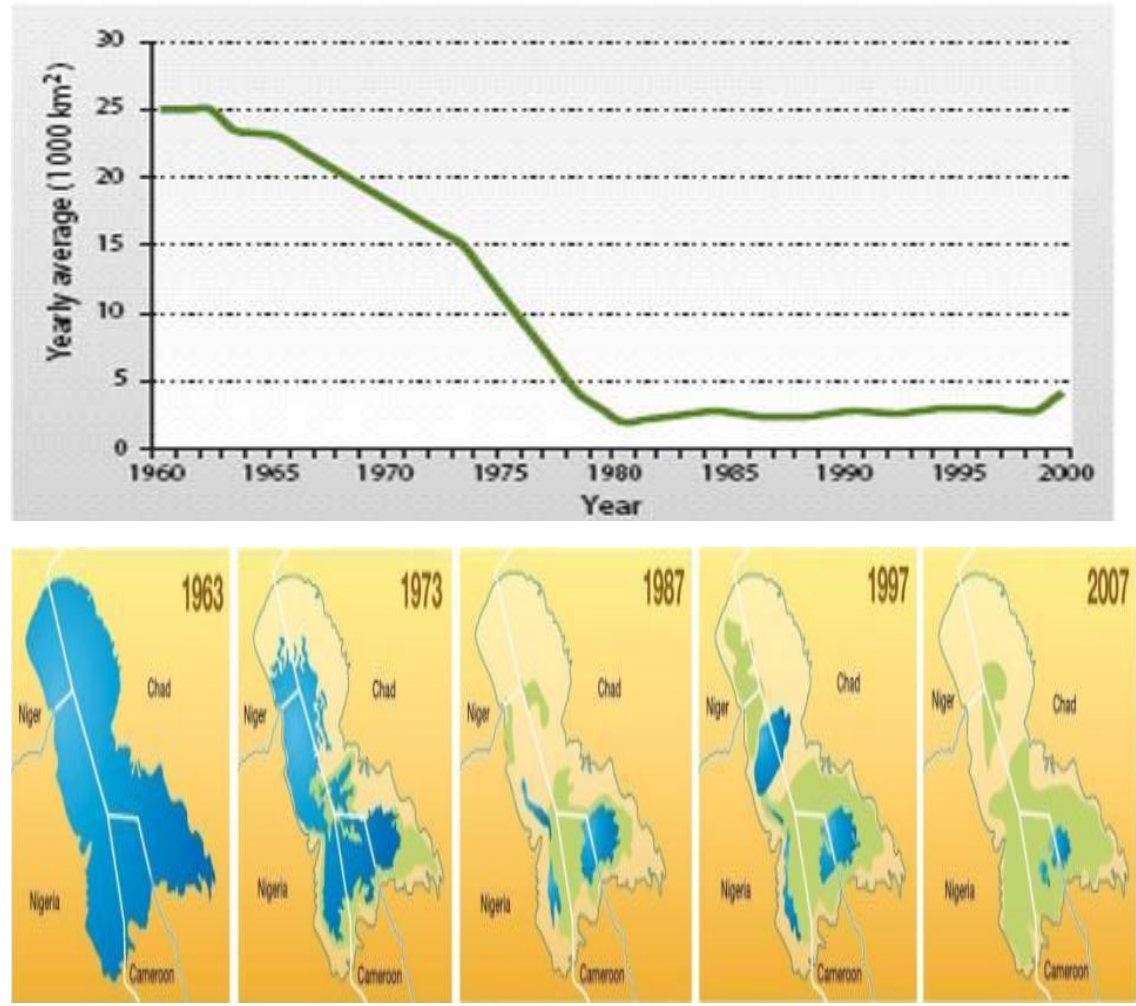

Fig. 1: Surface Area of Lake Chad under Different Scenarios (1963-2007) (Source: Google images- Planetforward.co)

The Lake Chad basin has been classified into 6 hydrological units. These are:

i. Lake Chad: approximately $25,000 \mathrm{~km} 2$, with an elevation of $279 \mathrm{~m}$. This section is undergoing serious shrinkage. The adjacent land is facing overgrazing.

ii. Lower Chari: this is the most important segment of the basin. It is the zone collecting water that feed the lakes. It has the largest rivers. 
iii. Flood plains of the Logona: it covers about $25,000 \mathrm{~km}^{2}$. It contains Grand Yaeres and the Waga national parks. It is a major livestock, fisheries and fish spawning habitat.

iv. Komadogu-Yobe: is a large basin which draws water from about $148,000 \mathrm{~km}^{2}$. It loses its water to infiltration and evapotranspiration. It has the largest numbers of dams it is the most densely populated. It has the Hadeija- Nguru wetland and the Kouri breed of cattle that is unique to the Lake Chad basin. This basin is vital to food production in Nigeria.

v. Borno drainages: it contains 3 rivers: Yedseram, Ngadda, Gobio. The Sambisa game reserve that is important to elephant conservation is located here. Others include: Hungurimi Duguma, Lake Chad game sanctuary section, Chad basin national park.

vi. Bornu diagnostic basin: is noted for its oasis, it supplies no inflow to the lake, it is an arid basin, and it is a zone of dune mobilization by trampling livestock and deforestation.

vii. Lake filtri: this is miniature lake Chad. It is rich in pasture. This zone is under intensive competition from indigenous people over grazing. It is a home to conflict over resource use.

Meanwhile, a trans-boundary diagnostic analysis study identified 7 environmental problems emanating from the present situation in the LCB (Lake Chad Basin). They include:

i. Variability in river regime and water availability: Lake Chad has decreased by about $95 \%$ from 1963. This has reduced access to water, culminated in crop failure, led to livestock death, collapsed fisheries, destroy wetland, services, lost of livelihood, caused unemployment, increased poverty, criminality, facilitated forced migration, and increased Hydropolitical conflicts within and around the LCB. It has high consequences in Nigeria, Niger Cameroon and Chad. 
ii. Decrease viability of biological resources: decreased viability of biological resources, degradation, deepening poverty, biodiversity loss.

iii. Loss of biodiversity of plant and animal species: damages to ecosystems, reduction in ecosystem productivity, availability of resources and has increased poverty,

iv. Pollution: this is mainly caused by the absence of environmental standards by relevant agencies in the basin. This has encouraged all forms of pollution in the lake. For example, the threat of inorganic fertilizers, other forms of chemical pollution and danger of eutrophification and the recent oil exploration exercises.

v. Loss and modification of ecosystem: the increasing desiccation due to climate change, coupled with increasing population and urbanization has endangered wetlands of the LCB. It has destroyed it by about $50 \%$, fisheries have collapsed and rice cultivation has been drastically affected.

vi. Sedimentation in rivers and water bodies: reduced inflow to the lakes and colonization of silted sites by water hyacinth are the most important consequences. These two phenomena have encouraged silt trapping in the lake. This has reduced the bank full capacity of Lake Chad. Unsustainable farming activities have further worsened the incidences of sedimentation in the LCB.

vii. Invasive species: weed of different types and pest of diverse origin are now presenting in the LCB. Common examples are the typha grass, water hyacinth which block rivers, divert flows, destroy infrastructure, and encourage quela bird. These have further worsened the situations and poverty margin and people's livelihood in the LCB.

\section{Ubangi river basin}

After a comparative study of 2 contagious basins of Congo River and Lake Chad the idea of a water transfer originated. The Ubangi river basin straddles the equator from $8^{\circ}$ North to about $12^{\circ}$ South of latitude, it is the largest 
African catchment and the second-largest in the world, after the Amazon River. The surface area is about $3,690,000 \mathrm{~km}^{2}$, it is 12 times the area of Italy, 10 times that of Germany, and 90 times the size of Switzerland. It drains $100 \%$ of the waters from the two republics of Congo, and others such as Central African Republic, Cameroon, Angola, Zambia, Tanzania, Burundi, and Rwanda (Vichi, 2011). Its geographic position straddling the equator, and its large size made this basin relatively unaffected by the seasonal variations in its flow. The annual averages at the mouth vary, based on the seasons, from 42,000 to $60,000 \mathrm{M}^{3} / \mathrm{sec}$. corresponding to an outflow of between 1,300 and 1,900 billion cubic meters of freshwater that flow annually ( Vichi ,2011).

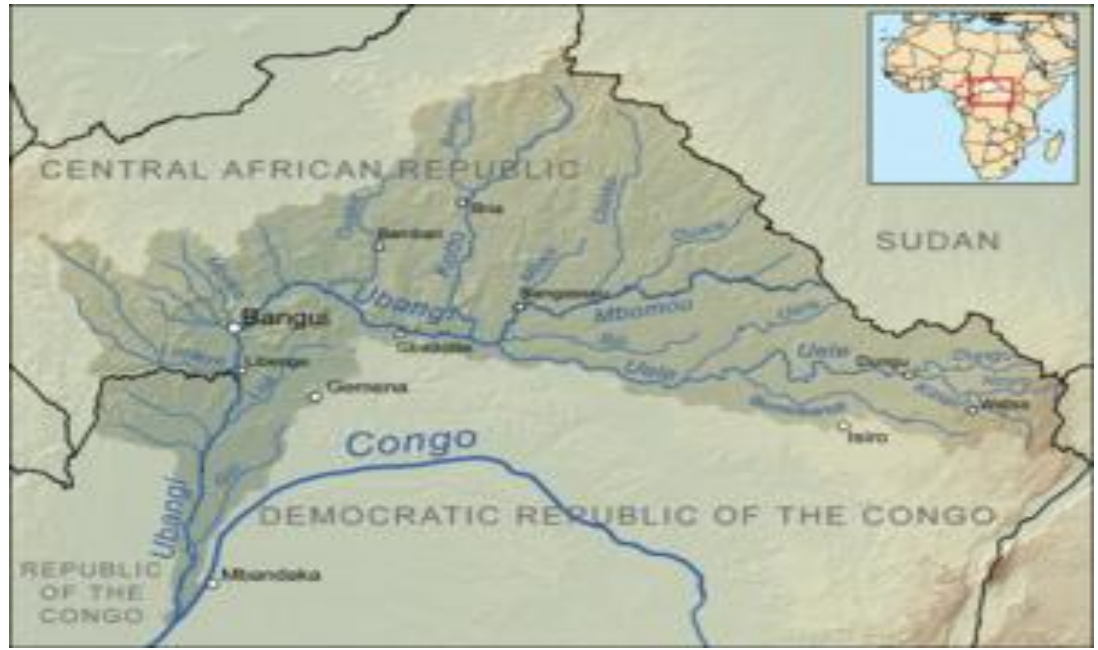

Figure 2: Ubangi (Oubangui) River Basin (Source: Wikipedia,2012)

The Ubangi River which is also known as Oubangui, is the largest tributary of the river Congo. It has a length of about 1,060 kilometers (Bossche, et al.1990). Together with the Congo River, it provides an important transport artery for river boats between Bangui and Brazzaville for over 100 kilometers from Bangui. It demarcates boundary between the Central African Republic and the Democratic Republic of the Congo (DRC) until it empties into the Congo River (Wikipedia, 2012). 
In the 1960s, a plan was proposed to divert waters from the Ubangi to the Chari River which empties into Lake Chad. According to the plan, the water from the Ubangi would revitalize the lake and provide livelihood in fishing and enhanced agriculture in Central and West Africa. Inter-basin water transfer schemes were proposed in the 1980s and 1990s by Nigerian Engineer J. Umolu and Italian firm Bonifica (TRANSAQUA Scheme) (Umolu, 1990). In 1994, the Lake Chad Basin Commission (LCBC) proposed a similar project and at a March 2008 summit, In April, 2008, the LCBC advertised a request for proposals for a feasibility study.

\section{National security in the north east of Nigeria: the Boko Haram crises}

The portion of Nigeria in the Lake Chad basin is currently one of the most politically volatile portions in Africa, especially in the states of Borno, Yobe, Gombe and Bauchi, where the suicide bombing and Islamic terrorism has been featuring more frequently in recent times. A cursory analysis of this crisis suggests that the issue at stake is that of environmental deprivation projected by the drying up $f$ the lake, which has rendered many jobless.

The above scenarios gave rise to the emergence of violent jihadist militant organizations amongst which is the Jama'atu Ahlis Sunnah Laddda' awatih Wal-Jihad otherwise known in Hausa as Boko Haram. This group has been most formidable of these groups. The group was founded in 2001 by Mohammed Yusuf. It has its headquarter in Kanamma, Nigeria; the opponents is the Nigeria state. It has strong resentment to anything western. It was founded by indigenous salafsit jihadist group; in 2009 it has turned to salafist jihadist. The founder of the group despite his level of education and lavish lifestyle resent western education. Before his death, he reiterated his ambition to change the current education system and rejecting democracy.

In 2011, Boko Haram was responsible for at least 450 killings in Nigeria, 620 deaths in the first 6 months of 2012. In the first few years 10,000 people have died (Wikipedia, 2012). Table 3 presents the time line of Boko Haram incidences in Nigeria.

More worrisome is the strategy and mode of recruitment and source of funding of this organization. For example, it was understood that this group uses the internet to propagate its activities and enhance radicalism and the circulation of extremist ideology. This organization is on serious evangelism of recruitment of members. They are on recruitment drive targeting muslin youth within the ages of 17 to 30 year. Recent source of information suggest 
that rather than the earlier believe the Boko Haram depend on donations from members, it has links with al-Qaeda in the Islamic Maghreb, which eventually exposed to funds from Saudi Arabia, and the United Kingdom. The source of fund also includes Al Muntada Trust Fund and the Islamic world society. It was also claimed that 2 states government paid on monthly basis to this group.

The above clearly showed that the poverty caused be deprivation and compounded with high level of illiteracy and massive youth unemployment has been a bane in the problem of political instability in the Nigeria Lake Chad region. In the recharging the lake will remain a major solution to this crisis.

A recent statistics released by the National Bureau of Statistics showed that Yobe state has the highest rate of youth unemployment, particularly youth within the ages of 15-24 years which stood at 39\% this standout as the highest in Nigeria $21 \%$. A recent study on poverty rate in Nigeria shows that the north east geopolitical zone has the highest level of poverty which stood at $77.7 \%$. It has a high rate of graduate unemployment. Nigeria has the $3^{\text {rd }}$ fastest rate of economic growth in the world. Evidences suggest that this growth is concentrated in few hands. About 40 million 18-25 year olds are unemployed. This scenario was captured by the 2012 poverty survey by NBS which revealed that $69 \%$ of Nigerians are defined as poor (112 million people), this is a great departure from the 1980 figure of 17 million. Indeed, the population of Nigeria is expected to increase from its current 63million to 389 million in 2050 to over 700 million by 2100 (UN). Currently, $71 \%$ of Nigeria is in relative poverty, this translates to $17 \%$ in 6 years. Furthermore, the perception of index of households living in poverty has risen to $92.5 \%$ in Bornu state, only $2 \%$ of children fewer than 25 months have been vaccinated, $83 \%$ are illiterate, and $48.5 \%$ of children under five do not go to hospital. The northern states of the northeast have highest proportion of uneducated persons, they lack opportunities, and have high male population. The northwest have the highest proportion of food poor, absolute poor, relative poor, and poor on the basis of a dollar per day (Rogers, 2012). All these have turned to disempowerment, resentment and anger which has eventually fanned the embers of terrorism in this part of Nigeria. Nigeria has in addition exposed to several long inter-ethnic conflicts and civil unrest rooted in poverty and economic competition has encouraged the emergence of different militia. This is been compounded by the issues of relatively political instability and corruption. The crisis of Boko Haram has been explained 
more often through the human need theory of social conflict approach (Rosati, et al 1990; Doherty and Pfaltzgrate; Kukah, 2012; Midlarsky, 1975). The conflict has also been explained through different school of thought, namely: relational/vengeance theory, political feud perspective, Islamic theocratic theory and through the conspiracy theories (Alozieuwa, 2013),

This clearly showed that the recharge of Lake Chad will go a long way in stemming the tide of terrorism in the region.

\section{Inter Basin Water Transfer in the Lake Chad basin (TRANSQUA Project)}

The concept of TRANSAQUA is a synthesis of two fundamental elements: the saving of Lake Chad through large-scale water transfer, and an international river and land transport network. This project is set to achieve the following:

i. Stop the drying up

ii. Restore lake level

iii. To facilitate the navigation and transportation of goods as well as tourism.

iv. Generate $700 \mathrm{mw}$ of electricity through hydropower.

v. Regulate the Bangui river flow.

vi. Clear the region of land lockedness nature and achieve regional integration, cooperation and security.

vii. Act as catalyst for the establishment of fishery and irrigation activities.

viii. Promote poverty alleviation, drought mitigation and control desertification.

The TRANSQUA involved the idea of inter basin water transfer. This project is to include construction of 2,500km navigable channel that will be parallel to Lagos - Mombasa Trans equatorial road. This is to draw water from Congo river. It entails construction of Palambo dam, construction of $150-170 \mathrm{~km}$ long tunnel/channel to connect the 2 basins. It also include river training/dredging to ensure discharge of $900 \mathrm{~m}^{3} / \mathrm{sec}$ and construction and rehabilitation of river plots. It is also to include necessary measures to improve the environment; it involves desilting and the linking of the north and south pool to the lake. The table 3 summarizes the history of the project since inception. 
This project is expected to cost 15 billion Euro (23 billion USA dollars). The possible donors such as UNDP, EC, French Development Agency, and EU are all skeptical concerning the project in view of the fact that the level of information is still low; their fear may also be in view of the weak nature of the countries involved.

The expectations are numerous and there is no doubt these will lead to a turning around in the landscape of the LCB and more importantly Nigeria.

The supposed advantages of the project will include the followings.

i. It will check desiccation and drying up of the lake, and gradually restore its normal level. Environmental degradation has been a serious issue in the Chad basin. Most recently, Odjugo (2010) used a 105 year data to assess temperature trend in Nigeria, he reported a steady increase in air temperature since the 1970s and he discovered that in 63\% of the period of study (1971-2005) temperature were above normal. He also confirmed that the rate of temperature increase is higher in semi-arid region than what obtains in the coastal areas of Nigeria, for the 105 years of his study. Odjugo (2010) reported an average increase of $1.7^{\circ} \mathrm{C}$ in air temperature for in Nigeria, $1.2{ }^{\circ} \mathrm{C}$ for Niger delta area and $2{ }^{\circ} \mathrm{C}$ for Sudan- Sahel zone of Nigeria. In addition, Ahmad and Ahmad (2000), IPCC (2001), NEST (2003), and Hangaveled, et al (2005) all reported increasing temperature, increasing evapotranspiration, decreasing rainfall amount in continental interiors, increasing rainfall in the coast, increasing intensity of weather related disasters. Political conflicts induced by climate change on water resources have been recorded in every part of west Africa such as the downstream half of Niger river between Nigeria and Niger, in the middle valley of Senegal- between Senegal and Mauritania, and in the Volta river area between Ghana and Burkina Faso, the southern part of lake Chad between Cameroun and Nigeria, etc (Niasse, 2005).

ii. It will ensure navigation and transportation of goods and services. The development of the project involves construction of $2,500 \mathrm{~km}$ navigable channel that will be parallel to Lagos Mombasa Trans equatorial road. This is to draw water from Congo river, construction of Palambo dam, 150-170km long tunnel/channel 
to connect 2 basins, river training/dredging to ensure discharge of $900 \mathrm{~m}^{3} / \mathrm{sec}$ and construction and rehabilitation of river ports. It also involves desilting, the linking of the north and south pool to the lake. This will boast both domestic and interregional trade. This will not only provide employment, it will boast GDP and the region will come alive. This project will transform this region to a major investment hub.

iii. It will regulate Bangui River and prolonged its current period of navigation: This basin drains $100 \%$ of the waters from two republics of Congo, and from Central African Republic, Cameroon, Angola, Zambia, Tanzania, Burundi, and Rwanda (Vichi, 2011). The Congo River is relatively unaffected by the seasonal variations in its flow. The annual averages at the mouth is approximately 42,000 to approximately $60,000 \mathrm{~m}^{3} / \mathrm{sec}$, corresponding to an outflow of between 1,300 and 1,900 billion cubic meters of freshwater that flow annually into the Atlantic Ocean (Vichi ,2011). It's the largest tributary in central Africa. It has a length of about 1,060 kilometers. (Bossche, et al.1990). Together with the Congo River, it provides an important transport artery for river boats between Bangui and Brazzaville. It empties into the Congo River (Wilkipadea, 2012). The basin is rich in water sources and it has a great hydropolitical implication on the socioeconomic activities of the sub region.

iv. It will change the socio-political status of nations in central Africa from landlocked state. The central Africa republic and West Africa has a population of nations of landlocked nations. They include DRC Congo, CAR, Sudan, Chad, Niger. These nations are generally poor and less developed. Beside their economies depend almost entirely on sister nations, the completion of this project with its $2,500 \mathrm{~km}$ navigable channel that will be parallel to Lagos Mombasa Trans equatorial road and construction of Palambo dam, $150-170 \mathrm{~km}$ long tunnel/ cannel to connect 2 basins, river training / dredging to ensure discharge of $900 \mathrm{~m}^{3} / \mathrm{sec}$ and construction and rehabilitation of river plots will create an international water ways which runs from central Africa to the north African region. This will change the political status of this nation. 
v. It encourages fishing and irrigation activities. The main largescale irrigation scheme is the Hadejia basin is the Kano River Irrigation Project (KRIP), it is about 13,280 ha with a cropping intensity of $150 \%$ with a potential for a further 7,000 ha. The organized fadama irrigation has been operated since 1975 by the ADPs with financial assistance from the World Bank. The ADPs supply credit to small famers to buy pumps and drill shallow wells. Existing fadama wash bores, tube wells and direct pumping in the states of Kano, Jigawa, Yobe and Borno total about 77,500 ha. The potential irrigation area is estimated to be 387,000 ha although this would depend largely on the groundwater potential; impact on the regional ecology. Its decline has been documented in a number of reports, especially Barber, et. al. (1991), Kimmage, et al. (1991), Thompson (1992). . The Lake Chad Basin Nigeria controls a substantial geographical area of lake Chad.

vi. It will culminate into regional cooperation and development. The proposed IBWT will be a perfect medium of promoting regional integration, particularly among the 3 regions. These are: Nigeria, Niger, and in the West Africa region, and with Cameroon, Congo republic, CAR, in the central Africa republic and with Algeria, Libya, and Sudan in the North Africa region. This will facilitate the expected integration which for many years has been clamoured for. It will assist in resolving the problem of international security challenges, which is gradually creeping in to the Maghreb region and West Africa; it is already having its toll in east Africa, particularly the book Haram/Alshabab insurgence network in the African continent, which has put the entire Africa in serious security challenge.

vii. Restoration of biodiversity and ecology: The fish habitat in the lake has been altered from open water environment to a predominantly marshy environment. On the other hand, Tilapia (Oreochronis) has remained the most predominant species of fish. Bird life is threatened by decreasing water levels that have resulted in loss of wetland habitats. The decreased inundated area of the Waza-Logone floodplain has been a major cause for the reduction in the number of kob, and the complete disappearance of buffalo, waterbuck, bushbuck and common duiker in the Waza National 
Park. An estimated 50\% of wetlands in the LCB have already been destroyed and $36 \%$ of fish species are threatened. This has translated into the loss of products that support livelihoods, besides the loss of fisheries. A case in point is the loss of a genetically unique rice cultivar in the Kamadougu-Yobe Basin. These developments have contributed to the entrenchment of poverty.

\section{Possible consequences of LCB IBWT}

However, the negative impact of the project could only be identified after a detailed EIA has been carried out. According to ICID, 2006 and Abdelrhman (2008) the following issues should be taken into consideration if the project is to achieve its objectives:

The challenges of introduction of non-indigenous organisms; changes in water quality; changes in hydrologic regimes; alteration of habitat; environmental impact on the existing hydrological regime; water availability and demand for the present and future scenarios; effect of climate conditions; nature of water bodies (rivers and lake); damage to existing natural systems; and pollution of air, soil, and water. Others include the challenges of mixing of two different waters.

Also, more water enhances sediment transport and a very thorough study of sediment erosion, transport, and deposition should be conducted for both the donor and receiver basins. Effects of sediment budget alteration in the donor basin before and after the proposed dam, quantitative and qualitative water available at intake and delivery points; geological characteristics; river morphological information; A clear agreement should be achieved on the tasks and responsibilities of those involved; the clear mode of financing for the required level of operation, maintenance, and management; the control measures and options for further improvement; and the cost - benefit analysis on each alternative option available. 


\section{References}

Abdelrhman, M.A. (2008) Final Report Overall Assessment of Efforts Related to Water Resources in Lake Chad Basin

Bossche, J.P. Vanden; G. M. Bernacsek (1990). Source Book for the Inland Fishery Resources of Africa, Volume 1. Food and Agriculture Organization of the United Nations. p. 338.

FAO (2009) Adaptive Water Management in the Lake Chad Basin Addressing current challenges and adapting to future needs World Water Week, Stockholm, August 16-22, 2009

ICID (2006). Experience with inter-basin water transfers for irrigation, drainage, and flood Management, Revised Draft Report Of ICID Task Force In Inter-Basin Water Transfers, International Commission on Irrigation and Drainage, New Delhi, INDIA.

http://www.icid.org/ibwt_draft_aug06.pdf

Intergovernmental Panel on Climate (IPCC) 2007, Climate Change 2007:

Synthesis Report. Summary For Policy Makers, available at: http://www.ipcc-wg1-ucar.edu/wg1/wg1-report.htm pp. 1-22.

LCBC Lake Chad Basin Commission (2000). The Lake Chad Basin Vision for 2025. Second World Water Forum.

LCBC (2007). Feasibility Study of the Inter-basin water transfer project from Oubangui River to Lake Chad. International Invitation For Bids For The Selection of Consultants and Engineering Firm, IIFB No. 001/LCBC/IBWTP/2007. July, 2007. 100p.

Molega, AU (2006). Rainfall anomalies in Nigeria. Journal of Arid Environment., 5(1): 1-8.

Nigerian Environmental Study/action Team (NEST), (2003), Climate change in Nigeria: A Communication Guide For Reporters And Educators, NEST, Ibadan.

Odjugo PAO (2010). General overview of climate change impacts in Nigeria. Journal of Human Ecology., 29(1): 47-55. 
Olaniran OJ (2002). Rainfall anomalies in Nigeria: The contemporary understanding, paper presented at the 55th Inaugural Lecture, University of Ilorin, Nigeria, p. 55.

Vichi, M. (2011) Transferring Water from the Congo to Lake Chad: The Transaqua Project EIR July 22, 2011, The Project for Water Transfer From Ubangui to Lake Chad, Schiller Conference http://www.larouchepub.com/eiw/public/2011/eirv38n2820110722/31-36_3828.pdf

Wateraid (2011) Wateraid Country Strategy (2010-2015) http://www.wateraid.org/ /media/Publications/WaterAid-nigeriacountry-strategy-2010-2015

WHO/UNICEF (2010) Joint Monitoring Report 2010: Progress On Sanitation And Drinking Water http://www.who.int/water_sanitation_health/monitoring/fast_facts/e $\underline{\text { n/index.html }}$

Umolu, J. C.; (1990), Macro Perspectives for Nigeria's Water Resources Planning, Proc. of the First Biennial National Hydrology Symposium, Maiduguri, Nigeria, pp. 218-262 (discussion of Ubangi-Lake Chad diversion schemes) 
Table 1: Major Existing Inter-basin Transfers

\begin{tabular}{|c|c|c|c|c|}
\hline Name & $\begin{array}{l}\text { Year Of } \\
\text { Construction }\end{array}$ & Length & $\begin{array}{l}\text { Capacity (Million } \\
\text { Cubic Meters/Year) }\end{array}$ & $\begin{array}{l}\text { Costs } \\
\text { (Us\$Bn) }\end{array}$ \\
\hline $\begin{array}{ll}\text { i. } & \text { California State Water } \\
& \text { Project (USA) }\end{array}$ & Early 1960s-1990s & $715 \mathrm{Km}$ & $\begin{array}{l}25(10,300 \text { Cubic } \\
\text { Feet/Sec })\end{array}$ & 5.2 \\
\hline \begin{tabular}{|ll} 
ii. & Colorado River \\
& Aqueduct (USA)
\end{tabular} & $1933-1941$ & $392 \mathrm{Km}$ & $\begin{array}{l}1603.5(1.3 \mathrm{~m} \text { Acre- } \\
\text { Feet/Year) }\end{array}$ & $?$ \\
\hline 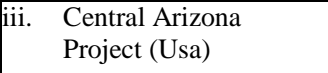 & $1973-93$ & $541 \mathrm{Km}$ & $\begin{array}{l}1850.2(1.5 \mathrm{~m} \text { Acre- } \\
\text { Feet/Year) }\end{array}$ & 3.6 \\
\hline iv. $\begin{array}{l}\text { National Water Carrier } \\
\text { (Israel) }\end{array}$ & $1953-64$ & $130 \mathrm{Km}$ & 1.7 & $?$ \\
\hline \begin{tabular}{|ll} 
v. & $\begin{array}{l}\text { Cutzamala System } \\
\text { (Mexico) }\end{array}$
\end{tabular} & $\begin{array}{l}\text { Late 1970s-Late } \\
\text { 1990s }\end{array}$ & $154 \mathrm{Km}$ & $2.1(24 \mathrm{M} 3 / \mathrm{Sec})$ & 1.3 \\
\hline $\begin{array}{ll}\text { vi. } & \begin{array}{l}\text { All-American Canal } \\
\text { (Usa) }\end{array}\end{array}$ & $1930 \mathrm{~s}$ & $132 \mathrm{Km}$ & $64(740 \mathrm{M} 3 / \mathrm{Sec})$ & $?$ \\
\hline iii. $\quad$ Periyar Project (India) & $\begin{array}{l}\text { Commissioned In } \\
1895\end{array}$ & $?$ & $3.5(41 \mathrm{M} 3 / \mathrm{Sec})$ & $?$ \\
\hline iii. $\begin{array}{l}\text { Indira Gandhi Canal } \\
\text { (India) }\end{array}$ & Since 1958 & $650 \mathrm{Km}$ & $?$ & $?$ \\
\hline $\begin{array}{ll}\text { ix. } & \begin{array}{l}\text { Telugu Ganga Project } \\
\text { (India) }\end{array}\end{array}$ & $1977-2004$ & $406 \mathrm{Km}$ & $\begin{array}{l}\text { 10.1 (3.7 Bn } \\
\text { M3/Year) }\end{array}$ & $?$ \\
\hline \begin{tabular}{|ll} 
x. & Irtysh-Karaganda \\
& Scheme (Kazakhstan)
\end{tabular} & $1962-1974$ & $450 \mathrm{Km}$ & $6.5(75 \mathrm{M} 3 / \mathrm{Sec})$ & $?$ \\
\hline
\end{tabular}

Source: Extracted from Wikipedia (2012) 
Table 2: An Overview of timeline of Boko Haram strikes in Nigeria

\begin{tabular}{|c|c|}
\hline $7^{\text {th }}$ September, 2010 & Bauchi prison break \\
\hline $31^{\text {st }}$ December,2010 & December 2010 Abuja attack \\
\hline $22^{\text {nd }}$ April, 2011 & Book Haram frees 14 prisoners during a jail break in Yola, \\
\hline $29^{\text {th }}$ May 2011 & May 2011 northern Nigeria bombings \\
\hline $16^{\text {th }}$ June, 2011 & $\begin{array}{l}\text { The group claims responsibility for the } 2011 \text { Abuja police headquarters } \\
\text { bombings. }\end{array}$ \\
\hline $26^{\text {th }}$ June, 2011 & $\begin{array}{l}\text { Bombing attack on a beer garden in Maiduguri leaving } 25 \text { dead and } 12 \\
\text { injured. }\end{array}$ \\
\hline $10^{\text {th }}$ July, 2011 & Fellowship church in Suleja, Niger state. \\
\hline $11^{\text {th }}$ July, 2011 & Temporary closes down its campus citing security concerns. \\
\hline $12^{\text {th }}$ August, 2011 & Prominent Muslim cleric Liman Bana was shot dead \\
\hline $26^{\text {th }}$ August , 2011 & 2011 Abuja bombing \\
\hline $4^{\text {th }}$ November, 2011 & 2011 Damaturu attacks \\
\hline $25^{\text {th }}$ December, 2011 & December 2011 attacks. \\
\hline 5-6 $6^{\text {th }}$ January 2012 & January 2012, Nigeria attacks \\
\hline $20^{\text {th }}$ January, 2012 & January 2012, Kano attacks \\
\hline $28^{\text {th }}$ January, 2012 & Nigeria army killed 11 Boko Haram insurgents \\
\hline $8^{\text {th }}$ February, 2012 & $\begin{array}{l}\text { Book Haram responsibility for a suicide bombing at the army } \\
\text { headquarters in Kaduna }\end{array}$ \\
\hline $16^{\text {th }}$ February, 2012 & $\begin{array}{l}\text { Another prison break staged in central Nigeria, } 119 \text { prisoners are } \\
\text { released one warden killed. }\end{array}$ \\
\hline $8^{\text {th }}$ March, 2012 & $\begin{array}{l}\text { During a British hostage rescue attempt to free Italian engineer Franco } \\
\text { Lamolinara and Briton Christopher McManus, abducted in } 2011 \text { by a } \\
\text { splinter group Boko Haram, both hostages were killed. }\end{array}$ \\
\hline $31^{\text {st }}$ May, 2012 & 5 sect members and a German hostage were killed \\
\hline 3 June, 2012 & $\begin{array}{l}\text { Bauchi state Boko Haram claimed responsibility through spokesperson } \\
\text { Abu Qaqa. }\end{array}$ \\
\hline $17^{\text {th }}$ June, 2012 & $\begin{array}{l}\text { Suicide bombers strike three churches in Kaduna state. at least } 50 \\
\text { people were killed. }\end{array}$ \\
\hline $17^{\text {th }}$ June, 2012 & $\begin{array}{l}130 \text { bodies was found in plateau state, it is presumed they were killed } \\
\text { by book Haram members. }\end{array}$ \\
\hline $13^{\text {th }}$ July,2012 & 2 people died in Maiduguri after a strike by gunmen \\
\hline $30^{\text {th }}$ July, 2012 & 5 people died in Zaria after gunmen strike \\
\hline $14^{\text {th }}$ august, 2012 & 4 people died in Kaduna after gunmen attacked \\
\hline $26^{\text {th }}$ august, 2012 & Unknown number died after an attack in Maiduguri \\
\hline $23^{\text {rd }}$ September, 2012 & 2 people died in Bauchi after an attack \\
\hline $5^{\text {th }}$ October, 2012 & 1 person died in Maiduguri after an attack \\
\hline $6^{\text {th }}$ October, 2012 & $\begin{array}{l}\text { Unknown number of people died in Taraba, and } 8 \text { people injured afrta } \\
\text { an attack }\end{array}$ \\
\hline $8^{\text {th }}$ October, 2012 & About 35 people causality were recorded in an attack \\
\hline $28^{\text {th }}$ October, 2012 & 8 people died in Kaduna, while 100 people were injured in an attack \\
\hline $2^{\text {nd }}$ November, 2012 & 2 policeman shot dead at Minna., Niger state \\
\hline
\end{tabular}




\begin{tabular}{|c|c|}
\hline $14^{\text {th }}$ November, 2012 & Explosions at Bauchi state police station \\
\hline $25^{\text {th }}$ November, 2012 & Boko Haram kills 11 at Nigeria military church in Jaji, Kaduna state. \\
\hline $26^{\text {th }}$ Novenmber,2012 & Boko Haram attacked SARs headquarters Abuja \\
\hline $2^{\text {nd }}$ December,2012 & 10 people died after gunmen attack in Kano \\
\hline $22^{\text {nd }}$ December, 2012 & Gunmen attack on 2 telecom offices in Kano \\
\hline $25^{\text {th }}$ December,2012 & Boko Haram attack churches in Maiduguri \\
\hline $19^{\text {th }}$ January, 2013 & $\begin{array}{l}\text { Gunmen attack in Sokoto. } \\
\text { Attack on detachment of Nigerian troops to Mali, left } 2 \text { dead. }\end{array}$ \\
\hline $31^{\text {st }}$ January, 2013 & Boko Haram attacked police station in Kano. \\
\hline $8^{\text {th }}$ February, 2013 & $\begin{array}{l}\text { Gunmen killed } 10 \text { polio immunization workers and injured } 3 \text { others in } \\
\text { Kano. }\end{array}$ \\
\hline $16^{\text {th }}$ Febuary, 2013 & Gunmen killed 7 foreign construction workers in Ja maare \\
\hline $19^{\text {th }}$ February, 2013 & French family kidnapped \\
\hline 3 March, 2013 & Gunmen attempted a military barrack in Bornu, about 10 people died. \\
\hline $13^{\text {th }}$ March, 2013 & Boo Haram jtf gunfight leaves 5 terrorist dead in Sokoto \\
\hline $16^{\text {th }}$ March, 2013, & Boko Haram attacks prison in Bornu, sets in mate free. \\
\hline $18^{\text {th }}$ March, 2013 & $\begin{array}{l}\text { Boko Haram attacked schools and killed Malam Kachalla was shot } \\
\text { dead. }\end{array}$ \\
\hline
\end{tabular}

Source: Extracted from Wikipedia, and updated by author in 2013

Table 3: Brief history of the IBWT proposal

\begin{tabular}{|cl|}
\hline I. & $\begin{array}{l}\text { Late 80's: First proposal by BONIFICA, Italy (BONIFICA 1991): 2400 km long } \\
\text { canal, } 3200 \mathrm{~m}^{3} \mathrm{~s}^{1}{ }^{-} \text {discharge, irrigate } 7 \text { million ha, improve river transportation, and } \\
\text { generate hydroelectric power (35 GWh/year). }\end{array}$ \\
\hline II. & $\begin{array}{l}\text { 1989 : Second proposal by Nigerian National Power Authority, NEPA (Mott } \\
\text { MacDonald, 1991): construct dam at Bangui, pump water to LCB, generate } \\
\text { hydroelectric power. Preferred proposal by LCBC. }\end{array}$ \\
\hline III. & February 1990: Pre-feasibility study by Central African Republic (SOGREAH), \\
\hline IV. & $\begin{array}{l}\text { 1990): construct dam at Palambo, IBWT, improve navigability, and produce } \\
\text { hydroelectric power. }\end{array}$ \\
\hline
\end{tabular}




\begin{tabular}{|c|c|}
\hline V. & 1992: LCBC Master Plan (LCBC 1992): identify IBWT as a priority \\
\hline VI. & 1994: LCBC 8th session: member states commitment to IBWT (LCBC, 2005a) \\
\hline VII. & $\begin{array}{l}\text { 1998: LCBC SAP (LCBC1998): request to initiate pre-feasibility studies for } \\
\text { IBWT }\end{array}$ \\
\hline VIII. & $\begin{array}{l}\text { March 1998: Visit of LCBC experts to Bangui LCBC (2005b): examine IBWT } \\
\text { Options }\end{array}$ \\
\hline IX. & $\begin{array}{l}\text { February 2000: Consultant report and a workshop (LCBC 2000): discuss } \\
\text { feasibility and pre-project for IBWT. }\end{array}$ \\
\hline $\mathrm{X}$. & $\begin{array}{l}2001: 1 \text { st meeting of LCBC-IBWT technical committee (LCBC 2005b): 1st } \\
\text { version of Terms of Reference adopted by member states September 2001 Tender } \\
\text { for Feasibility Study published (LCBC 2005a): } 5 \text { firms presented bids; process was } \\
\text { suspended for lack of funds. }\end{array}$ \\
\hline XI. & $\begin{array}{l}\text { January } 2002: 49 \text { th session of COM: Obtain non-objection to IBWT feasibility } \\
\text { study from all (except DRC), requests for funds submitted, LCBC committed one } \\
\text { million from the } 6 \text { million US } \$ \text { needed }\end{array}$ \\
\hline XII. & $\begin{array}{l}\text { June 2004: 51st session of COM: Nigeria's willingness to pay the total sum for } \\
\text { IBWT feasibility study and called for donor conference. }\end{array}$ \\
\hline XIII. & $\begin{array}{l}\text { August 2004: Meeting of experts from LCBC and DRC (LCBC 2005a,b): address } \\
\text { reservations about technical aspects of IBWT feasibility study. }\end{array}$ \\
\hline XIV. & $\begin{array}{l}\text { February 2005: } 2^{\text {nd }} \text { meeting of LCBC-IBWT technical committee (LCBC2005c): } \\
\text { address different aspects of IBWT project. } 6 \text { June } 200512 \text { th session of Heads of } \\
\text { State (CEEAC, 2005): stated non objection of IBWT donor states and permitted } \\
\text { LCBC to execute necessary Studies. }\end{array}$ \\
\hline $\mathrm{XV}$. & $\begin{array}{l}16 \text { June 2005: } 52^{\text {nd }} \text { session of COM (LCBC } 2005 \text { d): called for donor conference to } \\
\text { finance the remaining } 5 \text { million US } \$ \text { for the IBWT feasibility study. }\end{array}$ \\
\hline XVI. & $\begin{array}{l}30 \text { June 2005: Donor conference held with all heads of state (CBF 2005): } \\
\text { Supported LCBC to fundraise for IBWT studies; Nigeria committed the remaining } \\
5 \text { million US\$ for the feasibility study }\end{array}$ \\
\hline XVII. & August 2005 Terms of Reference for IBWT feasibility study (2005b): prepared \\
\hline XVIII. & $\begin{array}{l}\text { July } 2007 \text { International Competitive Bidding (ICB) for IBWT feasibility study } \\
\text { launched (LCBC 2007) }\end{array}$ \\
\hline
\end{tabular}

(Adapted from Mohammed, 2008) 